\title{
Anarchism and Psychology
}

\section{Dennis Fox ${ }^{1}$}

Many anarchists are suspicious of "psychologizing" and make little reference to psychology as a discipline beyond dismissing its individualist focus. Yet psychological assumptions about power, hierarchy, cooperation, and similar dynamics underlie critiques of statism and capitalism and shape prefigurative efforts to transform society so that human beings can more easily achieve both autonomy and mutuality. At the same time, personal and interpersonal turmoil frequently hinder those efforts. The challenge is to determine which aspects of psychological research and psychotherapy, especially critical psychology and extensions of humanistic psychology and radical psychoanalysis, might help anarchists grapple simultaneously with both the personal and the political. [Article copies available for a fee from The Transformative Studies Institute. E-mail address: journal@transformativestudies.org Website: http://www.transformativestudies.org (C2011 by The Transformative Studies Institute. All rights reserved.]

KEYWORDS: Anarchism, Psychology, Social Psychology, Critical Psychology, Mental Health, Mental Illness, Human Nature.

\section{INTRODUCTION}

Referring to the merging within each of us of internal and external forces, Gustav Landauer wrote that "The State is a condition, a certain relationship between human beings, a mode of human behavior; we destroy it by contracting other relationships, by behaving differently" (Landauer, 1910, cited in Buber, 1958, p. 46). Like all worldviews, anarchism incorporates assumptions about human nature and human

\footnotetext{
${ }^{1}$ Address correspondence to: Dennis Fox; e-mail: denfox@gmail.com.
} 